\section{Clinical features and molecular analysis of arginine-vasopressin neurophysin II gene in long-term follow-up patients with idiopathic central diabetes insipidus}

\author{
Apresentação clínica e análise molecular do gene da \\ arginina-vasopressina neurofisina II de pacientes com \\ diabetes insípido central idiopático com longo seguimento
}

Sergio L. Batista', Ayrton C. Moreira ${ }^{2}$, Jose Antunes-Rodrigues', Margaret de Castro², Lucila L. K. Elias', Paula C. L. Elias²

\begin{abstract}
Introduction: Central diabetes insipidus (DI) characterized by polyuria, polydipsia and inability to concentrate urine, has different etiologies including genetic, autoimmune, post-traumatic, among other causes. Autosomal dominant central DI presents the clinical feature of a progressive decline of arginine-vasopressin (AVP) secretion. Objective: In this study, we characterized the clinical features and sequenced the AVP-NPII gene of seven long-term follow-up patients with idiopathic central DI in an attempt to determine whether a genetic cause would be involved. Methods: The diagnosis of central DI was established by fluid deprivation test and hypertonic saline infusion. For molecular analysis, genomic DNA was extracted and the AVP-NPII gene was amplified by polymerase chain reaction and sequenced. Results: Sequencing analysis revealed a homozygous guanine insertion in the intron 2 (IVS2 +28 InsG) of the AVP-NPII gene in four patients, which represents an alternative gene assembly. No mutation in the code region of the AVP-NPII gene was found. Conclusions: The homozygous guanine insertion in intron 2 (IVS2 +28 InsG) is unlikely to contribute to the AVP-NPII gene modulation in DI. In addition, the etiology of idiopathic central DI in children may not be apparent even after long-term follow-up, and requires continuous etiological surveillance. Arq Bras Endocrinol Metab. 2010;54(3):269-73
\end{abstract}

Keywords

Central diabetes insipidus; AVP-NPI/ gene; PCR; sequencing; mutation

\section{RESUMO}

Introdução: O diabetes insípido (DI) central, caracterizado por poliúria, polidipsia e inabilidade em concentrar a urina, apresenta diferentes etiologias, incluindo causas genética, autoimune, pós-traumática, entre outras. O DI central autossômico dominante apresenta a característica clínica de falência progressiva da secreção da arginina-vasopressina (AVP). Objetivo: No presente estudo, caracterizou-se a apresentação clínica e sequenciou-se o gene AVP-NPII de sete pacientes com DI central idiopático seguidos de longa data na tentativa de determinar se uma causa genética estava envolvida na etiologia. Métodos: 0 diagnóstico do DI central foi estabelecido por meio do teste de jejum hídrico e infusão de salina hipertônica. Para a realização da análise molecular, o DNA genômico foi extraído e o gene AVP-NPII foi amplificado pela reação em cadeia da polimerase e, posteriormente, sequenciado. Resultados: $A$ análise do sequenciamento do gene AVP-NPII revelou uma inserção em homozigose de uma guanina no íntron 2 (IVS2 +28 InsG) em quatro pacientes, correspondendo a um arranjo alternativo do gene. Nenhuma mutação da região codificadora do gene AVP-NPII foi encontrada. Conclusões: A inserção em homozigose de uma guanina no íntron 2 (IVS2 +28 InsG) provavelmente não contribui na modulação do gene AVP-NPII no DI. Adicionalmente, a etiologia do DI central idiopático em crianças pode não se tornar evidente mesmo após um longo período de seguimento, necessitando de contínua vigilância da etiologia. Arq Bras Endocrinol Metab. 2010;54(3):269-73

Descritores

Diabetes insípido central; gene AVP-NPII; PCR; sequenciamento; mutação
'Departamento de Fisiologia, Faculdade de Medicina de Ribeirão Preto, Universidade de São Paulo (FMRP-USP),

Ribeirão Preto, SP, Brasil

${ }^{2}$ Departamento de Clínica Médica, FMRP-USP, Ribeirão Preto, SP, Brasil

Correspondence to:

Paula C. L. Elias

Divisão de Endocrinologia,

Departamento de Clínica Médica,

Faculdade de Medicina de Ribeirão Preto, USP

Av. Bandeirantes, 3.900

14049-900 - Ribeirão Preto, SP, Brasil

lamparelli@hotmail.com

Received on Oct/15/2009 Accepted on Nov/5/2009 


\section{INTRODUCTION}

C Central diabetes insipidus (DI) is a heterogeneous disease characterized by polyuria and polydipsia and failure to concentrate urine leading to a consequent excretion of large volumes of dilute urine. It is caused by a deficient secretion of arginine-vasopressin (AVP) by the neurohypophysis (1).

Although rare, familial inherited forms account for some cases of central DI (2-4). Genetic causes of central DI are usually due to gene mutations that encode AVP and its intracellular binding protein, neurophysinII ( $A V P$-NPII gene) and include autosomal dominant (2) and recessive forms (5). The AVP-NPII gene is located on chromosome 20 and contains three exons: exon 1 encodes the signal peptide, AVP peptide and the amino-terminal region of neurophysin-II; exon 2 encodes the central region of neurophysin-II; and exon 3 encodes the carboxy-terminal region of neurophysinII and co-peptin, a glycoprotein (6). Most of the mutations causing autosomal dominant central DI have been described in the gene portion encoding neurophysin-II $(2,7,8)$, leading to an improper folding and dimerization of neurophysin-II which accumulates in the endoplasmic reticulum $(3,9,10)$. The onset of vasopressin deficiency in autosomal dominant familial central neurohypophyseal DI (adFNDI) usually becomes gradually apparent during the first decade of life, and is associated with a progressive degeneration of vasopressin-producing magnocellular neurons in the supraoptic and paraventricular nuclei of the hypothalamus $(2,8,11)$. The neuron degeneration is probably due to a cytotoxic effect of the retained vasopressin-neurophysin-II in the magnocellular neurons $(3,9,12)$. In addition, the dimerization between the wild type and the mutant precursors may occur, leading to a dominant negative mechanism that may contribute to the pathogenesis of adFNDI (13).

The destruction or degeneration of vasopressinergic neurons can be due to different acquired etiologies such as intrasellar tumors, granulomatous disease, trauma, inflammatory and vascular disease (1). Nevertheless, central DI is still considered idiopathic in $15 \%$ to $50 \%$ of patients (14-16) and its etiology should be pursued, especially in those patients with other anterior pituitary deficiencies and pituitary stalk thickening (17). Therefore, periodic clinical, laboratorial and imaging evaluations by magnetic resonance imaging (MRI) are required during the follow-up of patients with idiopathic central DI in order to rule out associ- ated anterior pituitary deficiencies or cerebral diseases $(17,18)$. However, even after long-term follow-up, the etiology of the so-called idiopathic central DI remains not established in many patients (19). In the present study we aimed to evaluate the clinical presentation and the molecular analysis of the AVP-NPII gene in patients with idiopathic central DI with onset of symptoms during childhood.

\section{PATIENTS AND METHODS}

We studied seven patients ( 5 male, 2 female) with idiopathic central DI after obtaining informed consent and the approval of the University Hospital Ethics Committee. The diagnosis of central DI was based on the fluid deprivation test (20) or on hypertonic saline infusion (21). Anterior pituitary function was evaluated at baseline or stimulated pituitary hormone measurements using standard previously published immunoassays (22).

Central nervous system MRI was performed in all but one patient who was lost to follow-up in 1995, before the technique was available at the hospital.

\section{Molecular analysis}

Genomic DNA was extracted from peripheral blood samples using a QIAmp kit (Qiagen Inc., Valencia, CA, USA), and the AVP-NPII gene was amplified by polymerase chain reaction (PCR) using specific primers. For exon 1, the sense TGG CGG CCG CGT CTC GCC TCC ACG GGA ACA and antisense GCT ATG GCT GCC CTG AGA TGG CCC ACA GTG primers, were used; for exons 2 and 3 and their intronic region, the sense TCG CTG CGT TCC CCT CCA ACC CCT CGA CTC and antisense CCT CTC TCC CCT TCC CTC TTC CCG CCA GAG primers, were used. The PCR reaction was carried out with $10 \%$ DMSO, using the hot start method followed by forty cycles of amplification (exon $\mathrm{l}: 1$ minute at $95^{\circ} \mathrm{C}, 1$ minute at $66^{\circ} \mathrm{C}$ and 1 minute at $72^{\circ} \mathrm{C}$; exons 2 and $3: 1$ minute at $95^{\circ} \mathrm{C}, 1$ minute at $60^{\circ} \mathrm{C}$ and 1 minute at $72^{\circ} \mathrm{C}$ ). PCR products were visualized in $1 \%$ agarose gel followed by automated sequencing (ABI 377; Applied Biosystems). DNA sequencing was compared to data described by Bahnsen and cols. (23) (GenBank access number X62890).

\section{RESULTS}

Clinical and laboratory findings of studied patients are presented in table 1 . None of the patients had family 
Table 1. Clinical, radiological and laboratory data for patients with central diabetes insipidus

\begin{tabular}{|c|c|c|c|c|c|c|c|c|c|c|c|c|c|}
\hline Patient & $\begin{array}{c}\text { Age at } \\
\text { diagnosis } \\
\text { (years)/ } \\
\text { Genre }\end{array}$ & $\begin{array}{c}\text { Follow-up } \\
\text { (years) }\end{array}$ & $\begin{array}{l}\text { Familial } \\
\text { history }\end{array}$ & $\begin{array}{c}\text { Diuresis } \\
(\mathrm{mL} / \mathrm{kg} / \mathrm{d})\end{array}$ & $\begin{array}{l}\text { Basal } \\
\text { serum } \\
\text { sodium }\end{array}$ & $\begin{array}{l}\text { Basal } \\
\text { p0sm }\end{array}$ & $\begin{array}{l}\text { Basal } \\
\text { u0sm }\end{array}$ & $\begin{array}{c}\text { Maximum } \\
\text { p0sm } \\
\text { post- } \\
\text { dehydrata- } \\
\text { tion } \\
\end{array}$ & $\begin{array}{c}\text { Maximum } \\
\text { u0sm } \\
\text { post- } \\
\text { dehydrata- } \\
\text { tion } \\
\end{array}$ & 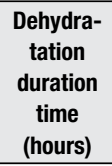 & $\begin{array}{c}\text { Minimum } \\
\text { p0sm } \\
\text { post- } \\
\text { desmo- } \\
\text { pressin } \\
\end{array}$ & $\begin{array}{c}\text { Maximum } \\
\text { u0sm } \\
\text { post- } \\
\text { desmo- } \\
\text { pressin }\end{array}$ & Image (MRI) \\
\hline \multirow[t]{2}{*}{1} & $3.6 / \mathrm{M}$ & 28 & Present & 250 & 143 & 296 & 72 & 307 & 291 & 6 & 295 & 466 & $\begin{array}{c}\text { Normal hypophysis } \\
\text { volume }\end{array}$ \\
\hline & & & & & & & & & & & & & Bright spot not presen \\
\hline 2 & $3.7 / \mathrm{F}$ & 30 & Absent & 320 & 135 & 296 & 64 & - & 84 & 2 & 300 & 600 & $N / A$ \\
\hline \multirow[t]{2}{*}{3} & $6 / M$ & 34 & Present & - & 147 & 300 & 298 & - & - & - & - & - & $\begin{array}{c}\text { Reduced hypophysis } \\
\text { volume }\end{array}$ \\
\hline & & & & & & & & & & & & & $\begin{array}{l}\text { Progressive bright } \\
\text { spot loss }\end{array}$ \\
\hline \multirow[t]{2}{*}{4} & $7 / M$ & 7 & Absent & 143 & 143 & 289 & 51 & 294 & 50 & 3 & 281 & 180 & $\begin{array}{l}\text { Normal hypophysis } \\
\text { volume }\end{array}$ \\
\hline & & & & & & & & & & & & & Bright spot not presen \\
\hline \multirow[t]{2}{*}{5} & $5.8 / \mathrm{M}$ & 28 & Absent & 150 & 150 & 286 & 46 & 318 & 52 & 6 & 280 & 502 & $\begin{array}{c}\text { Normal hypophysis } \\
\text { volume }\end{array}$ \\
\hline & & & & & & & & & & & & & $\begin{array}{l}\text { Progressive bright } \\
\text { spot loss }\end{array}$ \\
\hline \multirow[t]{3}{*}{6} & $7.5 / \mathrm{M}$ & 16 & Absent & 200 & 144 & 291 & 70 & - & - & - & - & - & $\begin{array}{c}\text { Normal hypophysis } \\
\text { volume }\end{array}$ \\
\hline & & & & & & & & & & & & & $\begin{array}{l}\text { mild infundibulum } \\
\text { thickness }\end{array}$ \\
\hline & & & & & & & & & & & & & $\begin{array}{l}\text { Progressive bright } \\
\text { spot loss }\end{array}$ \\
\hline \multirow[t]{2}{*}{7} & $1 / F$ & 10 & Absent & 206 & 127 & 293 & 64 & 294 & 591 & 8 & 290 & 717 & $\begin{array}{c}\text { Normal hypophysis } \\
\text { volume }\end{array}$ \\
\hline & & & & & & & & & & & & & Bright spot not presen \\
\hline
\end{tabular}

M: male; F: female; p0sm: plasma osmolality; uOsm: urinary osmolality; MRI: magnetic resonance image.

history of diabetes insipidus except patients 1 and 3 who were third-degree cousins but had no other relatives affected. Also, no autoimmune disease was identified in any of the nine patients. Age at onset of polyuria and polydipsia varied from 1 to 7 years of age, and duration of symptoms at diagnosis varied between 2 months and 5 years. Polyuria and polydipsia were the presenting symptoms in all patients, whose urinary volume at diagnosis ranged from 3 to $13.3 \mathrm{~L} / 24 \mathrm{~h}$ (143 to $320 \mathrm{~mL} /$ $\mathrm{kg} /$ day). The fluid deprivation test and vasopressin ana$\log$ responses were consistent with the diagnosis of total central DI in all but one patient that had a response compatible with partial central DI (Patient 6). Growth retardation and bone age delay were observed in patients 1 and 7. Adrenal and thyroid functions and pubertal development were normal in all patients. Patients were followed for 22 years at our out-patient clinic.

No expansive sella turcica lesions were visualized by imaging study in any patient, except patient 6 who showed mild infundibulum thickness and a pars intermedia cyst, which disappeared during follow-up. Initial sella turcica MRI studies in six patients resulted in the absence of the posterior pituitary hyperintense signal in three patients and its presence in three patients also; which lost the bright spot of the neurohypophysis in subsequent MRI during follow-up. Only one patient showed a reduced anterior pituitary.

Sequencing of $A V P-N P I I$ gene revealed no mutations in exons 1, 2 and 3 in any patients. However, a homozygous insertion of an additional guanine in intron 2 (IVS2 +28 InsG) was found in 4 patients. Due to the latter finding, we also sequenced $A V P$-NPII gene from controls and the same insertion in intron 2 was found in three out of nine controls.

\section{DISCUSSION}

In this study we presented seven patients with central DI diagnosed during the infancy with no apparent etiology after long-term follow-up. Molecular analysis of AVP-NPII gene showed no mutations in the coding region of this gene.

In the present series the age of onset for symptoms of polyuria and polydipsia was between 1 and 7 years of age, median of 5.8 years, very similar to the median age of 6.4 years reported by Maghnie and cols. (16) in a multi-centric study of pediatric patients with central DI. In our cohort, all patients but one were diagnosed within 6 months after the onset of symptoms. The literature usually describes a more dilated latency between 
the onset of symptoms and the diagnosis, with previous reports showing an interval of 4 years (24). The delay of the diagnosis of diabetes insipidus in pediatric patients suggests that clinicians may not be aware of the need to investigate the symptoms of polyuria and polydipsia in children.

Growth retardation and bone age delay were observed in patients 1 and 7 , which are in accordance with the $20 \%$ to $35 \%$ of patients with idiopathic central DI and short stature previously described $(16,24,25)$.

All seven patients in this series had no clear etiology for the vasopressin deficiency, despite the follow-up of 3 to 34 years. In an attempt to uncover the etiology of the disease in these patients, we carried out molecular analysis of the AVP-NPII gene. Although we found no mutation in the AVP-NPII gene in this series of DI patients, Rutishauser and cols. (10) previously reported a de novo AVP-NPII gene mutation in a patient with early onset of central DI and no family history, suggesting that genetic testing may be useful in patients who develop idiopathic DI during childhood.

While no mutation in the coding region was found, we identified a homozygous guanine insertion in intron 2 (IVS2 +28 InsG) in 4 patients. This insertion has also been described by Bahnsen and cols. (23) (GenBank access X62891) with a concomitant mutation in the coding region (Gly57Ser). As the authors performed direct gene sequencing in only one member of the kindred of 6 affected members, we do not know whether the $\mathrm{G}$ insertion was also present in their other patients or non-affected individuals, and the authors do not discuss this particular issue. Moreover, an error due to $\mathrm{PCR} /$ sequencing technique problems is less likely to account for our findings since the result was found in both, sense and antisense sequences as well as in repeated PCR experiments. Indeed, finding the G insertion in 3 out of 9 controls indicated that this variation might represent an alternative gene assembly that is unlikely to contribute to the AVP-NPII gene modulation (26).

The presence of vasopressin-secreting cell autoantibodies in association with pituitary stalk thickening suggests autoimmunity in almost $100 \%$ of patients with apparent idiopathic central DI (27). However, circulating human hypothalamus vasopressin-secreting cell autoantibodies have also been reported in patients with different causes of central DI (19,27-29), including Langerhans cell histiocytosis and germinoma; therefore, the presence of these antibodies may not be a reliable marker of autoimmune central DI (29). In the present study, determination of autoantibodies to vasopressin secreting cells was not available, therefore, we could not rule out an autoimmune cause of central DI, especially in patient 6 , who showed pituitary stalk thickness.

Although, pituitary stalk thickening in patients with central DI can be reversible and transient, as reported by De Buyst and cols. (24), the finding of pituitary stalk thickening in patients with central DI strongly indicates the need for long-term follow-up, since organic cause of central DI, such as germinoma and Langerhans cell histiocytosis, has been associated with isolated central DI with pituitary stalk thickening $(18,30)$.

In the present study, brightness signal of the posterior lobe on magnetic resonance Tl-weighted images was absent in five patients. The absence of posterior pituitary bright signal has been associated with central DI (31-33). On the other hand, presence of the signal may not indicate normal vasopressin secretion (31). Mahoney and cols. (34) studied the kindred with adFNDI by magnetic resonance imaging and showed the presence of the posterior pituitary hypertensive signal in all affected children, but an absent or barely visible signal in all adult patients but one, suggesting a progressive loss of the posterior pituitary signal in this inherited form of DI. In fact, three out of six patients in the current study presented a normal posterior pituitary signal, which disappeared later during follow-up, indicating progressive development of MRI features, similar to the decrease in AVP secretion (8).

It is important to point out that vascular abnormality should also be considered as a plausible cause of vasopressin deficiency in the present series of patients, since abnormal arterial blood flow affecting posterior pituitary blood supply has been previously described in patients with idiopathic central DI and normal anterior pituitary and pituitary stalk size with absence of posterior pituitary bright signal in the MRI (35).

In conclusion, we found a homozygous guanine insertion in intron 2 (IVS2 +28 InsG) in the AVP-NPII gene in DI patients as well as in controls, suggesting an alternative gene assembly that is unlikely to contribute to the AVP-NPII gene modulation. In addition, we confirm that the etiology of idiopathic central DI in children may not be apparent even after long-term follow-up, and requires continuous etiological surveillance.

Acknowledgements: This work was supported by Fapesp (grant number 07/58365-3).

Disclosure: no potential conflict of interest relevant to this article was reported. 


\section{REFERENCES}

1. Verbalis JG. Diabetes insipidus. Rev Endocr Metab Disord. 2003;4(2):177-85.

2. Christensen JH, Rittig S. Familial neurohypophyseal diabetes insipidus - an update. Semin Nephrol. 2006;26(3):209-23.

3. Ito $\mathrm{M}$, Jameson JL, Ito $\mathrm{M}$. Molecular basis of autosomal dominant neurohypophyseal diabetes insipidus. Cellular toxicity caused by the accumulation of mutant vasopressin precursors within the endoplasmic reticulum. J Clin Invest. 1997;99(8):1897-905.

4. Rittig S, Robertson GL, Siggaard C, Kovacs L, Gregersen N, Nyborg J, et al. Identification of 13 new mutations in the vasopressin-neurophysin II gene in 17 kindreds with familial autosomal dominant neurohypophyseal diabetes insipidus. Am J Hum Genet. 1996;58(1):107-17.

5. Willcutts MD, Felner E, White PC. Autosomal recessive familial neurohypophyseal diabetes insipidus with continued secretion of mutant weakly active vasopressin. Hum Mol Genet. 1999;8(7):1303-7.

6. Sausville E, Carney D, Battey J. The human vasopressin gene is linked to the oxytocin gene and is selectively expressed in a cultured lung cancer cell line. J Biol Chem. 1985;260(18):10236-41.

7. Siggaard C, Christensen JH, Corydon TJ, Rittig S, Robertson GL, Gregersen N, et al. Expression of three different mutations in the arginine vasopressin gene suggests genotype-phenotype correlation in familial neurohypophyseal diabetes insipidus kindreds. Clin Endocrinol (Oxf). 2005; 63(2):207-16.

8. Elias PC, Elias LL, Torres N, Moreira AC, Antunes-Rodrigues J, Castro M. Progressive decline of vasopressin secretion in familial autosomal dominant neurohypophyseal diabetes insipidus presenting a novel mutation in the vasopressin-neurophysin II gene. Clin Endocrinol (Oxf). 2003;59(4):511-8.

9. Siggaard C, Rittig S, Corydon TJ, Andreasen PH, Jensen TG, Andresen BS, et al. Clinical and molecular evidence of abnormal processing and trafficking of the vasopressin preprohormone in a large kindred with familial neurohypophyseal diabetes insipidus due to a signal peptide mutation. J Clin Endocrinol Metab. 1999;84(8):2933-41.

10. Rutishauser J, Kopp P, Gaskill MB, KotlarTJ, Robertson GL. Clinical and molecular analysis of three families with autosomal dominant neurohypophyseal diabetes insipidus associated with a novel and recurrent mutations in the vasopressin-neurophysin II gene. Eur J Endocrinol. 2002;146(5):649-56.

11. Nijenhuis M, Zalm R, Burbach JP. Mutations in the vasopressin prohormone involved in diabetes insipidus impair endoplasmic reticulum export but not sorting. J Biol Chem. 1999;274(30):21200-8.

12. Beuret N, Rutishauser J, Bider MD, Spiess M. Mechanism of endoplasmic reticulum retention of mutant vasopressin precursor caused by a signal peptide truncation associated with diabetes insipidus. J Biol Chem. 1999;274(27):18965-72.

13. Ito $\mathrm{M}, \mathrm{Yu} \mathrm{RN}$, Jameson JL. Mutant vasopressin precursors that cause autosomal dominant neurohypophyseal diabetes insipidus retain dimerization and impair the secretion of wild-type proteins. J Biol Chem. 1999;274(13):9029-37.

14. Greger NG, Kirkland RT, Clayton GW, Kirkland JL. Central diabetes insipidus. 22 years' experience. Am J Dis Child. 1986;140(6):551-4.

15. Wang LC, Cohen ME, Duffner PK. Etiologies of central diabetes insipidus in children. Pediatr Neurol. 1994;11(4):273-7.

16. Maghnie M, Cosi G, Genovese E, Manca-Bitti ML, Cohen A, Zecca S, et al. Central diabetes insipidus in children and young adults. $\mathrm{N}$ Engl J Med. 2000;343(14):998-1007.

17. Maghnie M. Diabetes insipidus. Horm Res. 2003;59(Suppl 1):42-54.

18. Mootha SL, Barkovich AJ, Grumbach MM, Edwards MS, Gitelman SE, Kaplan SL, et al. Idiopathic hypothalamic diabetes insipidus, pituitary stalk thickening, and the occult intracranial germinoma in children and adolescents. J Clin Endocrinol Metab. 1997;82(5):1362-7.
19. De Bellis A, Colao A, Bizzarro A, Di Salle F, Coronella C, Solimeno $S$, et al. Longitudinal study of vasopressin-cell antibodies and of hypothalamic-pituitary region on magnetic resonance imaging in patients with autoimmune and idiopathic complete central diabetes insipidus. J Clin Endocrinol Metab. 2002;87(8):3825-9.

20. Miller M, Dalakos T, Moses AM, Fellerman H, Streeten DH. Recognition of partial defects in antidiuretic hormone secretion. Ann Intern Med. 1970;73(5):721-9.

21. Zerbe $\mathrm{RL}$, Robertson GL. A comparison of plasma vasopressin measurements with a standard indirect test in the differential diagnosis of polyuria. N Engl J Med. 1981;305(26):1539-46.

22. Amato MC, Elias LL, Elias J, Santos AC, Bellucci AD, Moreira AC, et al. Endocrine disorders in pediatric - onset Langerhans Cell Histiocytosis. Horm Metab Res. 2006;38(11):746-51.

23. Bahnsen U, Oosting P, Swaab DF, Nahke P, Richter D, Schmale H. A missense mutation in the vasopressin-neurophysin precursor gene cosegregates with human autosomal dominant neurohypophyseal diabetes insipidus. EMBO J. 1992;11(1):19-23.

24. De Buyst J, Massa G, Christophe C,Tenoutasse S, Heinrichs C. Clinical, hormonal and imaging findings in 27 children with central diabetes insipidus. Eur J Pediatr. 2007;166(1):43-9.

25. Czernichow P, Pomarede R, Basmaciogullari A, Brauner R, Rappaport R. Diabetes insipidus in children. III. Anterior pituitary dysfunction in idiopathic types. J Pediatr. 1985;106(1):41-4.

26. Ye L, Li X, ChenY, Sun H, Wang W, SuT, et al. Autosomal dominant neurohypophyseal diabetes insipidus with linkage to chromosome 20p13 but without mutations in the AVP-NPII gene. J Clin Endocrinol Metab. 2005;90(7):4388-93.

27. Pivonello R, De Bellis A, Faggiano A, Di Salle F, Petretta M, Di Somma $C$, et al. Central diabetes insipidus and autoimmunity: relationship between the occurrence of antibodies to arginine vasopressin-secreting cells and clinical, immunological, and radiological features in a large cohort of patients with central diabetes insipidus of known and unknown etiology. J Clin Endocrinol Metab. 2003;88(4):1629-36.

28. Scherbaum WA, Hauner H, Pfeiffer EF. Vasopressin cell surface antibodies in central diabetes insipidus detected on cultured human foetal hypothalamus. Horm Metab Res. 1985;17(11):622.

29. Maghnie M, Ghirardello S, De Bellis A, Di lorgi N, Ambrosini L, Secco A, et al. Idiopathic central diabetes insipidus in children and young adults is commonly associated with vasopressin-cell antibodies and markers of autoimmunity. Clin Endocrinol (Oxf). 2006;65(4):470-8.

30. Leger J, Velasquez A, Garel C, Hassan M, Czernichow P. Thickened pituitary stalk on magnetic resonance imaging in children with central diabetes insipidus. J Clin Endocrinol Metab. 1999;84(6):1954-60.

31. Maghnie M, Villa A, Arico M, Larizza D, Pezzotta S, Beluffi G, et al. Correlation between magnetic resonance imaging of posterior pituitary and neurohypophyseal function in children with diabetes insipidus. J Clin Endocrinol Metab. 1992;74(4):795-800.

32. Gudinchet F, Brunelle F, Barth MO, Taviere V, Brauner R, Rappaport $\mathrm{R}$, et al. MR imaging of the posterior hypophysis in children. Am J Roentgenol. 1989;153(2):351-4.

33. Fujisawa I. Magnetic resonance imaging of the hypothalamic-neurohypophyseal system. J Neuroendocrinol. 2004;16(4):297-302.

34. Mahoney $\mathrm{CP}$, Weinberger $\mathrm{E}$, Bryant $\mathrm{C}$, Ito $\mathrm{M}$, Jameson $\mathrm{JL}$, Ito $\mathrm{M}$. Effects of aging on vasopressin production in a kindred with autosomal dominant neurohypophyseal diabetes insipidus due to the DeltaE47 neurophysin mutation. J Clin Endocrinol Metab. 2002;87(2):870-6.

35. Maghnie M, Altobelli M, Di lorgi N, Genovese E, Meloni G, Manca-Bitti ML, et al. Idiopathic central diabetes insipidus is associated with abnormal blood supply to the posterior pituitary gland caused by vascular impairment of the inferior hypophyseal artery system. J Clin Endocrinol Metab. 2004;89(4):1891-6. 